\title{
New Approach to Chuncheon Dakgalbi Processing by Various Chicken Materials, Seasoning and Cooking Methods
}

\author{
Muhlisin, Sun Moon Kang ${ }^{1}$, Won Hee Choi, Cheon-Jei Kim², Byoung Ki An ${ }^{3}$, \\ Chang Won Kang ${ }^{4}$, and Sung Ki Lee* \\ Department of Animal Products and Food Science, Kangwon National University, Chuncheon 200-701, Korea \\ ${ }^{I}$ National Institute of Animal Science, Rural Development Administration, Suwon 441-706, Korea \\ ${ }^{2}$ Department of Food Science and Biotechnology of Animal Resources, Konkuk University, Seoul 143-701, Korea \\ ${ }^{3}$ College of Animal Bioscience and Technology, Konkuk University, Seoul 143-701, Korea \\ ${ }^{4}$ Departement of Animal Science and Environment, Konkuk University, Seoul 143-701, Korea
}

\begin{abstract}
This research was conducted to develop a new approach to Chuncheon Dakgalbi processing by various chicken materials, seasoning (conventional sauce/CS and new approach of seasoning by adding the curing mixture/CSA), and cooking methods. Three chicken breeds (broiler, old broiler and spent laying hen) were divided into five experimental groups: broiler-CS, old broiler -CS, old broiler-CSA, spent laying hen-CS, and spent laying hen-CSA. All samples were stored at $5^{\circ} \mathrm{C}$ for $12 \mathrm{~d}$. For sensory evaluation, all samples were cooked with conventional cooking (pan grilling) or high temperature and pressure cooking (at $121^{\circ} \mathrm{C}$ with pressure $1.5 \mathrm{Kg}_{\mathrm{f}} / \mathrm{cm}^{2}$ for $30 \mathrm{~min}$ ). The chicken material analysis showed that the moisture and crude protein content, cooking loss and shear-force of the old broiler and spent laying hen were higher $(p<0.05)$ than those of the current broiler, but the crude ash, crude lipid and WHC were lower $(p<0.05)$. The addition of CSA increased the $\mathrm{pH}$ value and reduced the lipid oxidation at the end of storage regardless of chicken breeds $(p<0.05)$. The high temperature and pressure cooking method seemed to increase the taste, smell and overall-acceptability scores of the old broiler and spent laying hen Chuncheon Dakgalbi regardless of the implementation of new approach of seasoning (CSA). In conclusion, an old broiler and spent laying hen can be used as material of Chuncheon Dakgalbi by the application of a new approach of seasoning and cooking method.
\end{abstract}

Key words: Chuncheon Dakgalbi, chicken breeds, seasoning, cooking method

\section{Introduction}

Chuncheon Dakgalbi was originally local cuisine in Chuncheon city, Kangwon province, but now become one of traditional food in Korea. It made by grilling a chicken mixed with sauce and vegetable including chili pepper paste, sliced cabbage, sweet potato and other ingredients. Generally, Chuncheon Dakgalbi is made from broilers No. 12 (average slaughter weight 1,150-1,250 g) and No. 14 (average slaughter weight 1,350-1,450 g) which gives a soft texture to consumer. As the increasing of Chuncheon Dakgalbi consumption, the demand of chicken carcass for Chuncheon Dakgalbi also is increasing. To increase the supply of Chuncheon Dakgalbi materials for

\footnotetext{
*Corresponding author: Sung Ki Lee, Department of Animal Products and Food Science, Kangwon National University, Chuncheon 200-701, Korea. Tel: 82-33-250-8646, Fax: 82-33-2517719, E-mail: skilee@kangwon.ac.kr
}

diversification, it is important to study the possibility of substituting the broiler with other breeds that are still limited in utilization.

Recently, the Korean poultry industry has faced problem in the utilization of spent laying hen meat, because most of consumers have not been consuming it. Moreover, this has caused environmental pollution and high disposal cost for carcass burning or burying (Jin et al., 2007). The possibility of the utilization of spent laying hens was reported by Jin et al. (2007) for producing sausage. Chuncheon Dakgalbi made by Korean native chicken showed good flavor and taste but low texture by sensory evaluation while Chuncheon Dakgalbi made from spent laying hens was evaluated to be low in sensory scores (Lee et al., 2011). According to these previous results, the possibility of the old broiler and spent laying hen as the material of Chuncheon Dakgalbi still need an improvement of the taste and texture.

It is known that curing process can be applied for 
increasing the texture, taste and flavor quality of meat products. The addition of curing agents plays a decisive role in obtaining the specific sensory properties, stability and hygienic safety of products (Hammes, 2012). Nitrite of the curing agents can increase the flavor and phosphate can enhance the texture properties. With the increasing age of the chicken, insoluble connective tissues are also increased (Gerrard and Grant, 2006). Those connective tissues components such as collagen and hydrophobic protein contained in old broiler and spent laying hens are responsible for their tough texture properties and this collagen which is stabilized by hydrogen bonds can be affected by the pressure treatment (Gekko and Koga, 1983). Moreover, the contractile myofibrillar proteins which are primarily responsible for the texture properties of the meat are also tended to be change when meat is subjected to high pressure treatment (Ma and Ledward, 2004). Those references noted that the pressure treatment might be applied to convert the tough meat including chicken meat to more tender meat. In addition, the combination of heat and pressure are reported to increase the meat tenderness and to prevent the myofibrillar component of toughness (Beiken et al., 1990; Bouton et al., 1977).

Although some studies reported the comparison of the quality of Chuncheon Dakgalbi made from different chicken breeds, there are still limited information regarding the use of old broiler and spent laying hen as the materials of Chuncheon Dakgalbi. Moreover, the development of seasoning and cooking method might be needed when the old broiler and spent laying hen are used as raw materials of Chuncheon Dakgalbi. Therefore, this research was conducted to develop the new approach to Chuncheon Dakgalbi processing by various chicken materials, seasoning and cooking methods.

\section{Material and Methods}

\section{Sample preparation}

The broiler (Cornish breeds; 1,200 g; 4 wk), old broiler
(Cornish breeds; 1,800 g; $80 \mathrm{wk}$ ), and spent laying hen (Hy-line brown breeds; 1,200 g; $60 \mathrm{wk}$ ) were supplied by a Jung Woo Food Co., Ltd., located in Pocheon of South Korea. After slaughtering of chickens, the carcasses were stored in a refrigerator $\left(5^{\circ} \mathrm{C}\right)$ for whole night and deboned at the next day ( $24 \mathrm{~h}$ after slaughtering). The deboned chicken legs were vacuum-packed and transported to laboratory.

\section{Chuncheon Dakgalbi processing and storing} Conventional and commercial method (CS)

The deboned chicken legs from three different breeds (broiler, old broiler and spent laying hen) were mixed with Chuncheon Dakgalbi sauce. The formulation of Chuncheon Dakgalbi sauce is presented in Table 1. All the ingredients of the sauce were separately mixed, and then the sauce was mixed with the leg meat (sauce:meat= 1:2). The mixtures were placed on a box container and the cap was tightly closed to limit the air penetration from outside. The Chuncheon Dakgalbi was stored on a refrigerator at $5^{\circ} \mathrm{C}$ for $12 \mathrm{~d}$.

\section{New approach method (mixing with curing agent/ CSA)}

The deboned chicken legs of the old broiler and spent laying hens were mixed with Chuncheon Dakgalbi sauce which was previously added with $1 \%$ of curing mixture (based on meat weight). The curing mixture contained sodium nitrite, phosphate, potassium erythorbate, Lglutamate, sugar, white pepper and allspices (See Table 1 for the detail formulation). The sauce and the curing mixture were separately mixed, followed by mixing with leg meat. The storing process was same with the process mentioned in point 1 (Conventional and commercial method/CS).

\section{Cooking of Chuncheon Dakgalbi}

For the sensory evaluation of cooked Chuncheon Dakgalbi, the conventional and commercial cooking method was compared with the new approach method.

Table 1. Chuncheon Dakgalbi sauce recipes

\begin{tabular}{|c|c|c|c|}
\hline \multicolumn{2}{|c|}{ Conventional sauce } & \multicolumn{2}{|c|}{ Curing mixture } \\
\hline Ingredients & Percent $(\%)$ & Ingredients & Percent $(\%)$ \\
\hline Soy sauce and pepper paste & 16.2 & Sodium nitrite & 0.94 \\
\hline Pepper etc. & 16.0 & FOS/ENR & 19.60 \\
\hline Sugar etc. & 17.3 & Potassium eyrthorbate & 3.70 \\
\hline Fresh garlic and onion & 28.9 & L-Glutamate & 14.00 \\
\hline Other ingredients & 18.1 & Sugar & 46.70 \\
\hline Water & 3.5 & Other ingredients & 15.06 \\
\hline
\end{tabular}


Conventional and commercial cooking method (pan grilling)

Briefly, the leg meats which were previously mixed with sauce were cut on the size of approximately $2 \times 2 \times 1$ $\mathrm{cm}$. Twenty $\mathrm{mL}$ of soy bean oil was heated on a frying pan (HM-2002, Daewo Home Electrics Co., Korea) with medium heat temperature $\left( \pm 180^{\circ} \mathrm{C}\right)$ for $5 \mathrm{~min}$. The Chuncheon Dakgalbi was grilled on the heated oil and it was flipped every $5 \mathrm{~min}$ for a total $20 \mathrm{~min}$.

New approach method-high temperature and pressure method

Briefly, the leg meats which were previously mixed with sauce were cut on the size of $2 \times 2 \times 1 \mathrm{~cm}$ and totally $300 \mathrm{~g}$ of Chuncheon Dakgalbi was packed using a retort pouch followed by vacuuming and sealing. The vacuumed retorts Chuncheon Dakgalbi were cooked on an autoclaved machine (Jeio Tech AC-13, Korea) at $121^{\circ} \mathrm{C}$ with pressure $1.5 \mathrm{Kg}_{\mathrm{f}} / \mathrm{cm}^{2}$ for $30 \mathrm{~min}$.

\section{Proximate analysis and $\mathrm{pH}$}

The leg meat as raw material of Chuncheon Dakgalbi was ground using meat chopper (M-125, Hankook Fujee Industries Co., Ltd., Korea) equipped with $4 \mathrm{~mm}$ plate. The proximate analysis including moisture, crude protein, crude fat and ash were performed by AOAC (2007). For $\mathrm{pH}$ measurement, briefly, $10 \mathrm{~g}$ sample was added with $100 \mathrm{~mL}$ of distilled water and then homogenized at 10,000 rpm for $60 \mathrm{~s}$ using a homogenizer (PH91, SMT Co. Ltd., Japan). The $\mathrm{pH}$ of the meat slurry at room temperature was measured using a $\mathrm{pH}$ meter (SevenEasy $\mathrm{pH}$, Mettler-Toledo $\mathrm{GmbH}$, Switzerland). Measurements were performed on triplicates in each sample.

\section{Water holding capacity, cooking loss and shear- force determination}

The water holding capacity (WHC) was performed according to filter paper pressed method (Grau and Hamm, 1953). Briefly, $0.3 \mathrm{~g}$ of ground leg meat was weighed on a Whatman filter paper (No. 2). The sample was pressed between 2 plexiglass plates for $5 \mathrm{~min}$. The area of pressed sample and water was measured using a planimeter (Super Planix $\alpha$, Tamaya Technics Inc., Japan). The WHC was calculated as follows: WHC $(\%)=$ (area of sample/ area of water) $\times 100$.

To determine the cooking loss, $100 \mathrm{~g}$ of leg meat was boiled individually in polyethylene bags immersed in an $80^{\circ} \mathrm{C}$ water bath for $30 \mathrm{~min}$. The sample was cooled for $30 \mathrm{~min}$. The initial weights of uncooked and cooked meat were recorded, and the cooking loss was calculated as follows: Cooking loss $(\%)=(($ uncooked weight - cooked weight)/uncooked weight $) \times 100$.

To determine shear-force, the Chuncheon Dakgalbi was cooked at $75^{\circ} \mathrm{C}$ to reach the internal temperature of $71^{\circ} \mathrm{C}$. After cooking, the Chuncheon Dakgalbi was cooled to room temperature for $2 \mathrm{~h}$. The cooked Chuncheon Dakgalbi was cut into cubes $(1 \times 1 \times 1 \mathrm{~cm})$ for shear-force measurement. Shear force determination was performed using a flat knife blade of a texture analyzer (TA-XT2i version 6.06, Stable Micro System, UK). The determination was performed 10 times in each sample and the shear-force was expressed as $\mathrm{kg}_{\mathrm{f}}$.

\section{Color measurement}

The Chuncheon Dakgalbi sample was minced using a meat chopper (M-125, Hankook Fujee Industries Co., Ltd., Korea) equipped with $4 \mathrm{~mm}$ plate. The samples were placed on a $90 \times 15 \mathrm{~mm}$ petridish and the surface was covered with polyethylene clean wrap. The instrumental color of lightness (CIE L*), redness (CIE a*) and yellowness $\left(\mathrm{CIE} \mathrm{b}^{*}\right)$ were determined using a color difference meter (CR-400, Konica Minolta Sensing Inc., Japan) which was previously calibrated using a white plate (Illuminant $\mathrm{C}: \mathrm{Y}=93.6, \mathrm{x}=0.3134$, and $\mathrm{y}=0.3194)$.

\section{Thiobarbituric acid reactive substances (TBARS) and volatile basic nitrogen (VBN)}

The TBARS value was measured according to Sinnhuber and Yu (1977). Briefly, 0.5 g sample was mixed with 3 drops of antioxidant solution (3\% BHA-54\% propylene glycol-3\% BHT-40\% Tween 20 ), $3 \mathrm{~mL}$ of TBA solution (1\% 4,6-Dihydroxy-2-mercaptopyrimidine), and $17 \mathrm{~mL}$ of $25 \%$ trichloroacetic acid. The mixture was heated at $100^{\circ} \mathrm{C}$ for $30 \mathrm{~min}$, and centrifuged at 3,500 rpm for 30 min. An absorbance of supernatant was measured at 532 $\mathrm{nm}$ using a spectrophotometer (UV-mini-1240, Shimadzu, Japan). The results were calculated as mg malonaldehyde (MA) per kg sample.

The analysis of VBN was measured using the method of Kohsaka (1975). Five gram sample was homogenized with $30 \mathrm{~mL}$ of $5 \%(\mathrm{w} / \mathrm{v})$ TCA using a homogenizer (UltraTurrax T25 basic, IkaWerke GmbH and Co., Germany) at $13,500 \mathrm{rpm}$ for $2 \mathrm{~min}$. The homogenate was made up to $50 \mathrm{~mL}$ of final volume with $5 \%(\mathrm{w} / \mathrm{v}) \mathrm{TCA}$ and filtered through a Whatman No. 1 filter paper. One $\mathrm{mL}$ of the filtrate and $1 \mathrm{~mL}$ of borate buffer were placed in outer and inner of Conway dish, respectively, and then incubated at $37^{\circ} \mathrm{C}$ for $100 \mathrm{~min}$. Finally, the inner solution was titrated 
with $0.01 \mathrm{~N} \mathrm{HCl}$.

\section{Sensory evaluation}

Sensory evaluation of Chuncheon Dakgalbi was conducted by a panel consisting of 20 members. The cooking methods of Chuncheon Dakgalbi were divided into conventional and commercial cooking (pan grilling) and new approach method (high temperature and pressure). The panel was asked to evaluate the color, taste, texture, smell and overall acceptability on a hedonic scale $(9=$ very good, $7=$ good, $5=$ acceptable, $3=$ poor, and $1=$ very poor).

\section{Statistical analysis}

All data were analyzed using SPSS statistic 19.0 for Windows Evaluation Version (2010). The proximate, WHC, cooking loss, shear-force and sensory evaluation data were analyzed by one way analysis of variance using Duncan's multiple range tests with examination for significant differences $(p<0.05)$ to obtain the difference among Chuncheon Dakgalbi treatment. The data of Chuncheon Dakgalbi quality during storage including $\mathrm{pH}$, TBARS and VBN were statistically analyzed to obtain the different among treatments and storage period.

\section{Results and Discussion}

\section{Characteristics of chicken as raw materials \\ Proximate analysis of chicken material}

The proximate analysis results are presented in Table 2. Both in meat sample with skin and without skin, the crude ash contents of broiler were the highest $(p<0.05)$ and spent laying hen showed the lowest among three chicken breeds. Regardless of the skin, the spent laying hen showed the highest $(p<0.05)$ contents of protein, and the lowest $(p<0.05)$ content of ash and lipid. The proximate analysis of poultry meat are influenced by several aspects, including breed, age, part of meat, nutrition, etc (Collins and

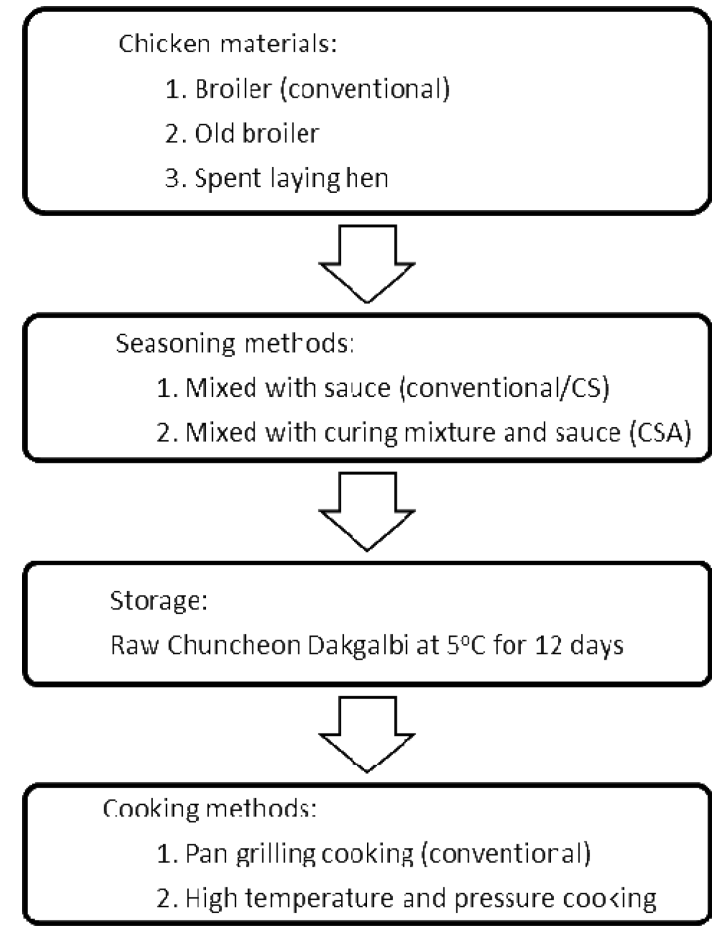

Fig. 1. Experimental design of Chuncheon Dakgalbi processing.

Moran, 1999). Franco et al. (2012) reported the significant difference in protein and ash content between two different chicken breeds. The moisture content of all samples (without skin) was ranged from 74.26 to $74.79 \%$. Similar with our data, Miguel et al. (2008) and Wattanachant et al. (2004) reported the moisture content of broiler was ranged 74 to $76 \%$. The protein contents of the samples (Table 2) was similar with the protein contents of broiler as reported by Wattanachant et al. (2004), but lower Franco et al. (2012) and Ding et al. (1999) (22.6 to 24.7\%). Our data was different with Smith et al. (2012), in which the moisture, protein, lipid and ash content of commercial broiler are $66.0 \%, 28.1 \%, 5.4 \%$, and $1.9 \%$ respectively. Wang et al. (2009) noted that strain and age have more effect on proximate analysis than rearing method.

Table 2. Proximate composition (\%) of leg meat of broiler, old broiler and spent laying hen

\begin{tabular}{|c|c|c|c|c|c|}
\hline \multirow{2}{*}{ Leg meat } & & \multicolumn{4}{|c|}{ Proximate parameters } \\
\hline & & Moisture & Ash & Protein & Lipid \\
\hline Broiler & & $74.26 \pm 0.19^{b}$ & $0.95 \pm 0.02^{\mathrm{a}}$ & $19.36 \pm 0.04^{\mathrm{c}}$ & $5.44 \pm 0.57^{\mathrm{a}}$ \\
\hline Old broiler & Without skin & $74.31 \pm 0.48^{\mathrm{ab}}$ & $0.81 \pm 0.03^{b}$ & $19.96 \pm 0.03^{b}$ & $4.91 \pm 0.44^{\mathrm{b}}$ \\
\hline Spent laying hen & & $74.79 \pm 0.28^{\mathrm{a}}$ & $0.71 \pm 0.07^{\mathrm{c}}$ & $20.22 \pm 0.09^{\mathrm{a}}$ & $4.28 \pm 0.35^{\mathrm{c}}$ \\
\hline Broiler & & $69.19 \pm 1.01^{x}$ & $0.79 \pm 0.06^{x}$ & $18.18 \pm 0.23^{z}$ & $11.84 \pm 0.60^{y}$ \\
\hline Old broiler & With skin & $68.06 \pm 0.52^{x y}$ & $0.70 \pm 0.06^{\mathrm{y}}$ & $18.39 \pm 0.21^{\mathrm{y}}$ & $12.85 \pm 1.71^{x}$ \\
\hline Spent laying hen & & $68.39 \pm 0.82^{y}$ & $0.61 \pm 0.02^{z}$ & $19.52 \pm 0.02^{x}$ & $11.48 \pm 0.70^{y}$ \\
\hline
\end{tabular}

Data are presented as Means \pm SD (Standard deviation, $\mathrm{n}=5$ ).

${ }^{\text {a-c } V a l u e s ~ w i t h i n ~ e a c h ~ c o l u m n ~(s a m p l e ~ w i t h o u t ~ s k i n) ~ w i t h ~ d i f f e r e n t ~ s u p e r s c r i p t s ~ a r e ~ s i g n i f i c a n t l y ~ d i f f e r e n t ~}(p<0.05)$.

${ }^{\mathrm{x}-\mathrm{z} V a l u e s}$ within each column (sample with skin sample) with different superscripts are significantly different $(p<0.05)$. 
Water holding capacity, cooking loss and shearforce

The water holding capacity (WHC) of broiler was $48.24 \%$, the highest among the samples, in which the WHC of old broiler and spent laying hen were $20.25 \%$ and $16.22 \%$ respectively (Table 3 ). In contrast, the cooking loss of old broiler (44.11\%) and spent layer (43.19\%) were higher $(p<0.05)$ compared to broiler $(35.68 \%)$. Therefore, old broiler and spent laying hen are not suitable raw material of Chuncheon Dakgalbi compared with broiler due to lower WHC and higher cooking loss. Compared with other report, the cooking loss of Thai indigenous chicken was 19 to $23 \%$ (Jaturasitha et al., 2008) and Gallician indigenous breed was 11 to $12 \%$ (Franco et al., 2012). Castellini et al. (2002) reported the cooking loss for organic chicken was 33\% and for broiler chicken was $31 \%$. WHC and cooking loss of raw chicken are different with reports and it affected on textural quality of processed meat. The shear-force of spent layer $\left(5.47 \mathrm{Kg}_{\mathrm{f}}\right)$ was higher compared to old broiler and broiler (4.52 and $0.96 \mathrm{Kg}_{\mathrm{f}}$ respectively). The slaughter age played role in the tenderness of meat, in which the shear-force value of broiler was low but in contrast the shear-force value of old broiler and spent laying hen were comparably higher. Franco et al. (2012) classified meat with shear-force higher than $2 \mathrm{~kg}_{\mathrm{f}}$ as very tender meat, and it affected by the slaughter age and chicken genotypes. The shear-force

Table 3. Water holding capacity/WHC (\%), cooking loss (\%), and shear-force $\left(\mathrm{Kg}_{\mathrm{f}}\right)$ of leg meat of broiler, old broiler and spent laying hen

\begin{tabular}{lccc}
\hline \hline \multicolumn{1}{c}{ Treatment } & WHC & Cooking loss & Shear-force \\
\hline Broiler & $48.24 \pm 2.34^{\mathrm{a}}$ & $35.68 \pm 1.79^{\mathrm{b}}$ & $0.96 \pm 0.24^{\mathrm{c}}$ \\
Old broiler & $20.25 \pm 0.91^{\mathrm{b}}$ & $44.11 \pm 2.05^{\mathrm{a}}$ & $4.52 \pm 1.08^{\mathrm{b}}$ \\
Spent laying hen & $16.22 \pm 1.67^{\mathrm{c}}$ & $43.19 \pm 1.66^{\mathrm{a}}$ & $5.47 \pm 1.03^{\mathrm{a}}$ \\
\hline
\end{tabular}

Data are presented as Means \pm SD (Standard deviation, $n=10$ ).

${ }^{\mathrm{a}-\mathrm{c}}$ Values within each column with different superscripts are significantly different $(p<0.05)$. increased with age due to the increase of hardness of connective tissue and the increase of collagen cross-linking (Aberle et al., 2001; Fletcher, 2002).

\section{Quality comparison of raw Chuncheon Dakgalbi during storage at $5^{\circ} \mathrm{C}$ \\ $\mathrm{pH}$ value}

The addition of curing mixture on Chuncheon Dakgalbi sauce (CSA) decreased $(p<0.05)$ the $\mathrm{pH}$ value of the raw Chuncheon Dakgalbi made from old broiler and spent laying hen on $0 \mathrm{~d}$ (Table 4). Curing mixture including sodium nitrite, and potassium erythorbate are responsible for the decrease of $\mathrm{pH}$ value in the raw Chuncheon Dakgalbi sample. The $\mathrm{pH}$ value of Chuncheon Dakgalbi made from broiler was higher compared with Chuncheon Dakgalbi made from old broiler and spent laying hen on 6 and $9 \mathrm{~d}$ of storage. These data showed that chicken breed (broiler $v s$ spent laying hen) and slaughtering age (broiler $v s$ old broiler) affected the $\mathrm{pH}$ value of leg meat. Chen et al. (2006) reported the significantly different of color and $\mathrm{pH}$ from different Chinese chicken breed. On the $3 \mathrm{~d}$ of storage, there was no difference on $\mathrm{pH}$ value among the treatments. The addition of curing agents started to increase $(p<0.05)$ the $\mathrm{pH}$ value both in raw Chuncheon Dakgalbi made from old broiler and spent laying hens started from $6 \mathrm{~d}$ until 12 of storage. Generally, the $\mathrm{pH}$ value tended to decrease on the early storage time followed by the increasing trend on the end of storage. The decrease of the $\mathrm{pH}$ value of meat products during storage time may be attributed by the presence of bacteria, such as lactic acid bacteria (Nychas et al., 1998). Some bacteria together with the enzyme system of the meat may break down the protein into ammonia and amino sugar complex that will increase the pH value (Jay and Shelf, 1978).

\section{Instrumental color}

The instrumental colors of raw Chuncheon Dakgalbi

Table 4. The pH value of raw Chuncheon Dakgalbi made with broiler, old broiler and spent laying hen mixed with conventionalsauce (CS) and new approach of seasoning (CSA) during storage at $5^{\circ} \mathrm{C}$

\begin{tabular}{|c|c|c|c|c|c|}
\hline \multirow{2}{*}{ Treatment } & \multicolumn{5}{|c|}{ Storage time $(\mathrm{d})$} \\
\hline & 0 & 3 & 6 & 9 & 12 \\
\hline Broiler-CS & $6.46 \pm 0.02^{\mathrm{aA}}$ & $6.27 \pm 0.03^{\mathrm{aA}}$ & $5.70 \pm 0.00^{\mathrm{bcB}}$ & $5.63 \pm 0.02^{\mathrm{bcB}}$ & $5.72 \pm 0.13^{\mathrm{dB}}$ \\
\hline Old broiler-CS & $6.45 \pm 0.04^{\mathrm{aA}}$ & $6.23 \pm 0.14^{\mathrm{aA}}$ & $5.46 \pm 0.07^{\mathrm{dC}}$ & $5.53 \pm 0.15^{\mathrm{cC}}$ & $5.80 \pm 0.06^{\mathrm{cdB}}$ \\
\hline Old broiler-CSA & $6.33 \pm 0.06^{\mathrm{bA}}$ & $6.27 \pm 0.03^{\mathrm{aA}}$ & $5.79 \pm 0.09^{\mathrm{abC}}$ & $5.77 \pm 0.01^{\mathrm{abC}}$ & $6.06 \pm 0.05^{\mathrm{bB}}$ \\
\hline Spent laying hen-CS & $6.38 \pm 0.04^{\mathrm{aA}}$ & $6.34 \pm 0.03^{\mathrm{aA}}$ & $5.58 \pm 0.11^{\mathrm{cdC}}$ & $5.60 \pm 0.02^{\mathrm{cC}}$ & $5.93 \pm 0.01^{\mathrm{bcB}}$ \\
\hline Spent laying hen-CSA & $6.32 \pm 0.03^{\mathrm{bA}}$ & $6.36 \pm 0.08^{\mathrm{aA}}$ & $5.91 \pm 0.01^{\mathrm{aB}}$ & $5.83 \pm 0.04^{\mathrm{aB}}$ & $6.26 \pm 0.04^{\mathrm{aA}}$ \\
\hline
\end{tabular}

Data are presented as Means \pm SD (Standard deviation, $n=5$ ).

${ }^{\mathrm{a}-\mathrm{d}}$ Values within each column with different superscripts are significantly different $(p<0.05)$.

${ }^{A-C}$ Values within each row with different superscripts are significantly different $(p<0.05)$. 
were shown in Table 5. Generally, the lightness value of Chuncheon Dakgalbi was fluctuated during the storage. The trends of unclear increase and decrease were observed in all the samples. On the experiment, we mixed the chicken leg meat with Chuncheon Dakgalbi sauce that is originally red color. It may cover the original color of the meat, so that, the effect of curing mixture on the instrumental color of the meat could not be obtained clearly. The CIE L* (lightness) of spent laying hen both with addition or without addition of curing mixture were lower $(p<0.05)$ than that of broiler and old broiler. From these data, it is suggested that the different breeds of chicken seemed to play role in the instrumental color value. Starting from $3 \mathrm{~d}$ of storage, the lightness of broiler was lower $(p<0.05)$ than old broiler and spent laying hen without addition of curing mixture. Chen et al. (2006) and Franco et al. (2012) reported the different instrumental color value of different chicken breed and different dietary. The addition of curing agents significantly decreased $(p<0.05)$ the lightness of old broiler and spent laying hen from $6 \mathrm{~d}$ and $3 \mathrm{~d}$ of storage respectively. The addition of curing mixture increased $(p<0.05)$ the redness value of old broiler on 3 and $6 \mathrm{~d}$ of storage, but it decreased from 9 to $12 \mathrm{~d}$ of storage. The curing mixture also increased $(p<0.05)$ the redness of spent laying hen on 6 to $9 \mathrm{~d}$ of
storage.The fixation of a desirable red color, shaded pink, is the most obvious effect from nitrite addition and is often considered an extremely important attribute for consumer acceptance (Cornforth and Jayasingh, 2004).

\section{Lipid oxidation (TBARS) and protein deterioration (VBN)}

The lipid oxidation of raw Chuncheon Dakgalbi, expressed as TBARS value were increased during storage in all the samples (Table 6). There was no effect $(p>0.05)$ of chicken breeds (broiler, old broiler and spent laying hen) and addition of curing agents on the lipid oxidation of Chuncheon Dakgalbi until $6 \mathrm{~d}$ of storage. After that, the addition of curing mixture decreased $(p<0.05)$ the lipid oxidation of Chuncheon Dakgalbi made from old broiler and spent laying hen, respectively. The curing mixture (including nitrite) effectively delayed the development of oxidative rancidity including lipid oxidation, even in the presence of salt which is a strong oxidant (Sindelar and Milkowski, 2011). In addition, Shahidi (1998) noted that the lipid oxidation is related with levels of unsaturated fats present in meat, as well as temperature, time, oxygen exposure, and the addition of antioxidant and reducing agents. Same trend can be seen on the protein deterioration data (VBN), in which the addition of curing agents

Table 5. The instrumental color value of raw Chuncheon Dakgalbi made with broiler, old broiler and spent laying hen mixed with conventional sauce (CS) and new approach of seasoning (CSA) during storage at $5^{\circ} \mathrm{C}$

\begin{tabular}{|c|c|c|c|c|c|c|}
\hline \multirow{2}{*}{ CIE } & \multirow{2}{*}{ Treatment } & \multicolumn{5}{|c|}{ Storage time $(\mathrm{d})$} \\
\hline & & 0 & 3 & 6 & 9 & 12 \\
\hline \multirow{5}{*}{$\mathrm{L}^{* 1)}$} & Broiler-CS & $53.59 \pm 1.36^{\mathrm{aA}}$ & $48.53 \pm 1.84^{\mathrm{bC}}$ & $50.25 \pm 2.15^{\mathrm{bB}}$ & $46.36 \pm 1.77^{\mathrm{bD}}$ & $47.57 \pm 1.75^{\mathrm{bCD}}$ \\
\hline & Old broiler-CS & $53.67 \pm 3.42^{\mathrm{aB}}$ & $51.41 \pm 1.39^{\mathrm{aC}}$ & $57.48 \pm 1.09^{\mathrm{aA}}$ & $54.27 \pm 0.98^{\mathrm{aB}}$ & $45.37 \pm 1.88^{\mathrm{cD}}$ \\
\hline & Old broiler-CSA & $49.73 \pm 3.18^{\mathrm{aA}}$ & $51.32 \pm 1.04^{\mathrm{aA}}$ & $47.73 \pm 1.39^{\mathrm{cB}}$ & $40.90 \pm 2.30^{\mathrm{dC}}$ & $42.15 \pm 1.44^{\mathrm{dC}}$ \\
\hline & Spent laying hen-CS & $52.33 \pm 1.87^{\mathrm{bA}}$ & $50.32 \pm 2.46^{\mathrm{aB}}$ & $49.99 \pm 1.94^{\mathrm{bB}}$ & $46.97 \pm 2.15^{\mathrm{bC}}$ & $53.88 \pm 1.91^{\mathrm{aA}}$ \\
\hline & Spent laying hen-CSA & $49.73 \pm 3.18^{\mathrm{bA}}$ & $46.52 \pm 2.04^{\mathrm{cB}}$ & $46.18 \pm 1.70^{\mathrm{dB}}$ & $44.27 \pm 1.31^{\mathrm{cC}}$ & $48.06 \pm 1.32^{\mathrm{bA}}$ \\
\hline \multirow{5}{*}{$a^{* 2)}$} & Broiler-CS & $18.67 \pm 1.35^{\mathrm{aB}}$ & $16.87 \pm 1.68^{\mathrm{cC}}$ & $18.05 \pm 0.98^{\mathrm{cB}}$ & $20.10 \pm 0.94^{\mathrm{aA}}$ & $20.14 \pm 0.75^{\mathrm{aA}}$ \\
\hline & Old broiler-CS & $18.42 \pm 2.27^{\mathrm{aB}}$ & $17.88 \pm 1.13^{\mathrm{cB}}$ & $18.40 \pm 0.76^{\mathrm{bcB}}$ & $19.56 \pm 1.17^{\mathrm{abA}}$ & $18.34 \pm 1.71^{\mathrm{bB}}$ \\
\hline & Old broiler-CSA & $16.72 \pm 1.93^{\mathrm{bB}}$ & $19.41 \pm 1.08^{\mathrm{aA}}$ & $20.21 \pm 2.05^{\mathrm{aA}}$ & $17.43 \pm 1.27^{\mathrm{cB}}$ & $16.75 \pm 2.24^{\mathrm{cB}}$ \\
\hline & Spent laying hen-CS & $19.04 \pm 1.43^{\mathrm{aA}}$ & $18.23 \pm 1.99^{\mathrm{bA}}$ & $19.23 \pm 1.75^{\mathrm{bA}}$ & $18.72 \pm 1.28^{\mathrm{bA}}$ & $17.98 \pm 1.78^{\mathrm{bA}}$ \\
\hline & Spent laying hen-CSA & $16.82 \pm 2.46^{\mathrm{bC}}$ & $16.63 \pm 1.60^{\mathrm{bC}}$ & $20.73 \pm 0.91^{\mathrm{aA}}$ & $20.23 \pm 1.32^{\mathrm{aA}}$ & $18.79 \pm 1.33^{\mathrm{bB}}$ \\
\hline \multirow{5}{*}{$b^{* 3)}$} & Broiler-CS & $34.37 \pm 2.79^{\mathrm{aA}}$ & $29.24 \pm 1.60^{\mathrm{cC}}$ & $32.22 \pm 2.88^{\mathrm{cB}}$ & $30.49 \pm 2.67^{\mathrm{bC}}$ & $30.23 \pm 2.54^{\mathrm{bC}}$ \\
\hline & Old broiler-CS & $34.33 \pm 2.79^{\mathrm{aC}}$ & $31.28 \pm 2.06^{\mathrm{bD}}$ & $44.25 \pm 1.77^{\mathrm{aA}}$ & $42.09 \pm 1.95^{\mathrm{aB}}$ & $28.70 \pm 2.41^{\mathrm{cD}}$ \\
\hline & Old broiler-CSA & $28.66 \pm 3.19^{\mathrm{bB}}$ & $36.55 \pm 1.98^{\mathrm{aA}}$ & $36.72 \pm 3.63^{\mathrm{bA}}$ & $24.70 \pm 2.98^{\mathrm{cC}}$ & $24.81 \pm 1.69^{\mathrm{dC}}$ \\
\hline & Spent laying hen-CS & $35.38 \pm 3.10^{\mathrm{bB}}$ & $31.92 \pm 2.24^{\mathrm{bC}}$ & $36.01 \pm 2.64^{\mathrm{bB}}$ & $29.89 \pm 2.53^{\mathrm{bC}}$ & $39.68 \pm 1.76^{\mathrm{aA}}$ \\
\hline & Spent laying hen-CSA & $30.61 \pm 1.98^{\mathrm{bB}}$ & $24.52 \pm 3.01^{\mathrm{dC}}$ & $33.94 \pm 2.52^{\mathrm{cA}}$ & $31.28 \pm 2.27^{\mathrm{bB}}$ & $29.49 \pm 1.95^{\mathrm{bcB}}$ \\
\hline
\end{tabular}

Data are presented as Means $\pm \mathrm{SD}$ (Standard deviation, $\mathrm{n}=20)$.

${ }^{\text {a-d } V a l u e s ~ w i t h i n ~ e a c h ~ c o l u m n ~ w i t h ~ d i f f e r e n t ~ s u p e r s c r i p t s ~ a r e ~ s i g n i f i c a n t l y ~ d i f f e r e n t ~}(p<0.05)$.

${ }^{A-D}$ Values within each row with different superscripts are significantly different $(p<0.05)$.

${ }^{1)} \mathrm{CIE} \mathrm{L}^{*}$ value (lightness)

${ }^{2)} \mathrm{CIE}$ a* value (redness)

${ }^{3)} \mathrm{CIE} \mathrm{b}^{*}$ value (yellowness) 
Table 6. The TBARS (mgMA/kg sample) value of raw Chuncheon Dakgalbi made with broiler, old broiler and spent laying hen mixed with conventional sauce (CS) and new approach of seasoning (CSA) during storage at $5^{\circ} \mathrm{C}$

\begin{tabular}{lccccc}
\hline \hline \multirow{2}{*}{ Treatment } & \multicolumn{5}{c}{ Storage time $(\mathrm{d})$} \\
\cline { 2 - 6 } & 0 & 3 & 6 & 9 & 12 \\
\hline Broiler-CS & $0.33 \pm 0.21^{\mathrm{aC}}$ & $1.52 \pm 0.15^{\mathrm{aB}}$ & $2.93 \pm 0.18^{\mathrm{aA}}$ & $2.94 \pm 0.17^{\mathrm{bcA}}$ & $4.00 \pm 0.25^{\mathrm{aA}}$ \\
Old broiler-CS & $0.40 \pm 0.17^{\mathrm{aE}}$ & $1.75 \pm 0.33^{\mathrm{aD}}$ & $2.94 \pm 0.41^{\mathrm{aC}}$ & $3.72 \pm 0.23^{\mathrm{aB}}$ & $4.24 \pm 0.29^{\mathrm{aA}}$ \\
Old broiler-CSA & $0.41 \pm 0.11^{\mathrm{aC}}$ & $1.53 \pm 0.09^{\mathrm{aB}}$ & $2.63 \pm 0.31^{\mathrm{aB}}$ & $2.76 \pm 0.41^{\mathrm{cB}}$ & $3.50 \pm 0.19^{\mathrm{bA}}$ \\
Spent laying hen-CS & $0.41 \pm 0.25^{\mathrm{aD}}$ & $1.69 \pm 0.15^{\mathrm{aC}}$ & $2.70 \pm 0.40^{\mathrm{aB}}$ & $3.25 \pm 0.37^{\mathrm{bAB}}$ & $3.82 \pm 0.66^{\mathrm{abA}}$ \\
Spent laying hen-CSA & $0.40 \pm 0.09^{\mathrm{aD}}$ & $1.64 \pm 0.19^{\mathrm{aC}}$ & $2.68 \pm 0.14^{\mathrm{aC}}$ & $3.09 \pm 0.06^{\mathrm{bcB}}$ & $3.29 \pm 0.39^{\mathrm{dA}}$ \\
\hline
\end{tabular}

Data are presented as Means \pm SD (Standard deviation, $n=5$ ).

${ }^{\text {a-d }}$ Values within each column with different superscripts are significantly different $(p<0.05)$.

${ }^{A-D}$ Values within each row with different superscripts are significantly different $(p<0.05)$.

Table 7. The VBN (mg\%) value of raw Chuncheon Dakgalbi made with broiler, old broiler and spent laying hen mixed with conventional sauce (CS) and new approach of seasoning (CSA) during storage at $5^{\circ} \mathrm{C}$

\begin{tabular}{lccccc}
\hline \hline \multirow{2}{*}{ Treatment } & \multicolumn{5}{c}{ Storage time (d) } \\
\cline { 2 - 6 } & 0 & 3 & 6 & 9 & 12 \\
\hline Broiler-CS & $12.89 \pm 1.02^{\mathrm{aE}}$ & $19.61 \pm 1.98^{\mathrm{aD}}$ & $29.20 \pm 1.22^{\mathrm{bC}}$ & $44.96 \pm 0.28^{\mathrm{aB}}$ & $49.65 \pm 0.90^{\mathrm{aA}}$ \\
Old broiler-CS & $13.01 \pm 0.65^{\mathrm{aE}}$ & $20.66 \pm 0.74^{\mathrm{aD}}$ & $32.84 \pm 0.90^{\mathrm{aC}}$ & $38.10 \pm 1.02^{\mathrm{bB}}$ & $43.28 \pm 1.67^{\mathrm{bA}}$ \\
Old broiler-CSA & $12.78 \pm 0.96^{\mathrm{aD}}$ & $19.89 \pm 0.32^{\mathrm{aC}}$ & $31.79 \pm 1.24^{\mathrm{abB}}$ & $31.93 \pm 0.46^{\mathrm{cB}}$ & $41.88 \pm 3.12^{\mathrm{bA}}$ \\
Spent laying hen-CS & $12.83 \pm 0.78^{\mathrm{aD}}$ & $20.38 \pm 0.27^{\mathrm{aC}}$ & $32.91 \pm 0.70^{\mathrm{aB}}$ & $33.05 \pm 3.74^{\mathrm{cB}}$ & $49.79 \pm 0.80^{\mathrm{aA}}$ \\
Spent laying hen-CSA & $12.75 \pm 0.80^{\mathrm{aE}}$ & $19.61 \pm 1.98^{\mathrm{aD}}$ & $29.20 \pm 1.22^{\mathrm{bC}}$ & $34.96 \pm 0.28^{\mathrm{cB}}$ & $49.65 \pm 0.90^{\mathrm{aA}}$ \\
\hline
\end{tabular}

Data are presented as Means \pm SD (Standard deviation, $n=5$ ).

${ }^{\mathrm{a}-\mathrm{d}}$ Values within each column with different superscripts are significantly different $(p<0.05)$.

${ }^{\text {A-D }}$ Values within each row with different superscripts are significantly different $(p<0.05)$.

decreased $(p<0.05)$ the VBN value of Chuncheon Dakgalbi both in old broiler and spent laying hen on 6 and 12 $\mathrm{d}$ of storage (Table 7). The addition of curing agents slightly decreased the protein deterioration both in old broiler and spent laying hen. Statistically, the addition of curing mixture decreased $(p<0.05)$ the lipid deterioration of old broiler only on $9 \mathrm{~d}$ and spent laying hen on $6 \mathrm{~d}$ of storage.

\section{Sensory comparison of Chuncheon Dakgalbi ac- cording to cooking method}

Sensory evaluation scores of cooked Chuncheon Dakgalbi are presented in Table 8. The cooking methods were divided into conventional and commercial (pan grilling), that is dry-heat method and new approach of cooking method (high temperature and pressure) that is moist heat. It is known that the texture of old broiler and

Table 8. The sensory evaluation score of cooked Chuncheon Dakgalbi made with broiler, old broiler and spent laying hen mixed with conventional sauce (CS) and new approach of seasoning (CSA)

\begin{tabular}{|c|c|c|c|c|c|c|}
\hline Treatment & Cooking methods & Color ${ }^{1)}$ & Taste $^{1)}$ & Texture $^{1)}$ & Smell ${ }^{1)}$ & $\begin{array}{c}\text { Overall- } \\
\text { acceptibility } 1)\end{array}$ \\
\hline Broiler-CS & \multirow{5}{*}{ Pan grilling $^{2)}$} & $7.8 \pm 1.0^{\mathrm{a}}$ & $7.5 \pm 1.3^{\mathrm{a}}$ & $7.9 \pm 1.1^{\mathrm{a}}$ & $7.7 \pm 0.8^{\mathrm{a}}$ & $7.9 \pm 0.5^{\mathrm{a}}$ \\
\hline Old broiler-CS & & $6.5 \pm 1.2^{b}$ & $6.2 \pm 1.5^{\mathrm{bc}}$ & $6.1 \pm 1.2^{b}$ & $6.4 \pm 1.1^{\mathrm{bc}}$ & $6.5 \pm 1.2^{b}$ \\
\hline Old broiler-CSA & & $6.6 \pm 1.1^{\mathrm{b}}$ & $7.3 \pm 1.5^{\mathrm{ab}}$ & $5.9 \pm 1.2^{\mathrm{b}}$ & $6.9 \pm 1.1^{\mathrm{ab}}$ & $6.8 \pm 1.0^{\mathrm{b}}$ \\
\hline Spent laying hen-CS & & $6.0 \pm 0.9^{b}$ & $5.2 \pm 1.4^{\mathrm{c}}$ & $4.4 \pm 1.0^{\mathrm{c}}$ & $5.6 \pm 0.9^{c}$ & $5.2 \pm 1.0^{\mathrm{c}}$ \\
\hline Spent laying hen-CSA & & $6.2 \pm 1.1^{\mathrm{b}}$ & $5.4 \pm 1.6^{\mathrm{c}}$ & $4.2 \pm 1.1^{\mathrm{c}}$ & $6.0 \pm 1.1^{\mathrm{c}}$ & $5.2 \pm 0.8^{\mathrm{c}}$ \\
\hline Old broiler-CS & \multirow{4}{*}{$\begin{array}{l}\text { High temperature } \\
\text { and pressure }\end{array}$} & $7.0 \pm 0.0^{\mathrm{b}}$ & $7.8 \pm 1.0^{\mathrm{a}}$ & $7.3 \pm 0.5^{\mathrm{a}}$ & $7.0 \pm 0.0^{\mathrm{a}}$ & $7.3 \pm 0.5^{\mathrm{ab}}$ \\
\hline Old broiler-CSA & & $8.3 \pm 0.5^{\mathrm{a}}$ & $7.8 \pm 0.5^{\mathrm{a}}$ & $7.3 \pm 0.5^{\mathrm{a}}$ & $7.3 \pm 0.5^{\mathrm{a}}$ & $8.0 \pm 0.0^{\mathrm{a}}$ \\
\hline Spent laying hen-CS & & $6.8 \pm 0.5^{\mathrm{b}}$ & $6.8 \pm 0.5^{\mathrm{a}}$ & $6.5 \pm 0.6^{\mathrm{b}}$ & $6.8 \pm 0.5^{\mathrm{a}}$ & $6.8 \pm 1.0^{\mathrm{b}}$ \\
\hline Spent laying hen-CSA & & $7.3 \pm 1.0^{\mathrm{b}}$ & $7.0 \pm 0.8^{\mathrm{a}}$ & $6.3 \pm 0.5^{\mathrm{b}}$ & $6.5 \pm 1.3^{\mathrm{ab}}$ & $6.8 \pm 1.0^{\mathrm{b}}$ \\
\hline
\end{tabular}

Data are presented as Means \pm SD (Standard deviation, $n=20$ ).

${ }^{a-c}$ Values within each column with different superscripts are significantly different $(p<0.05)$.

${ }^{1)}$ Hedonic score: 9 , very good; 7, good; 5 , acceptable; 3, poor; 1 , very poor

${ }^{2}$ Pan grilling, grilling on a frying pan with medium heat temperature $\left( \pm 180^{\circ} \mathrm{C}\right)$ for total $20 \mathrm{~min}$.

${ }^{3)}$ High temperature and pressure: cooking on an autoclaved machine at $121^{\circ} \mathrm{C}$ with pressure $1.5 \mathrm{Kg}_{\mathrm{f}} / \mathrm{cm}^{2}$ for $30 \mathrm{~min}$. 
spent laying hen meat are more though than that of normal broiler. So that, on sensory evaluation, we conducted the high temperature and pressure (retort packaging, $121^{\circ} \mathrm{C}, 1.5 \mathrm{Kg}_{\mathrm{f}} / \mathrm{cm}^{2}, 30 \mathrm{~min}$ ) as new approach of cooking method, in order to obtain the possibility of this cooking method to be used to the industrialization of Chuncheon Dakgalbi. Moreover, the relatively higher moisture available on autoclaving (moist-heat) than grilling (dry-heat) might be important in hydrolysis of collagen and other connective tissues (Judge et al., 1989), that is important in tenderizing the meat texture.

On the pan grilling cooking methods, Chuncheon Dakgalbi made from broiler showed highest $(p<0.05)$ sensory evaluation scores including color, taste, texture, smell, and overall acceptability among samples. There was no difference $(p>0.05)$ on the sensory evaluation score of color between old broiler and spent laying hen cooked with pan grilling method, while the sensory evaluation score of taste, texture, smell and overall acceptability of old broiler was higher than that of spent laying hen. The addition of curing mixture did not affect on the sensory evaluation scores in all parameters. On the high temperature and pressure cooking method, there were no difference $(p>0.05)$ on the sensory evaluation score of taste and smell between old broiler and spent laying hen. The addition of curing mixture also did not affect on those parameters. The taste and overall acceptability of old broiler were higher $(p<0.05)$ compared with spent laying hen regardless of the curing mixture addition. The addition of curing mixture only affected on the sensory evaluation score of color of Chuncheon Dakgalbi made form old broiler packed with retort (high temperature and pressure cooking method), in which the color of curing old broiler sample was higher $(p<0.05)$ than that of non addition sample.

The new approach of cooking method improved $(p<$ 0.05 ) the sensory scores in both old broiler and spent laying hen Chuncheon Dakgalbi, in comparison with conventional cooking method. The panel scored lower scores of color of Chuncheon Dakgalbi cooked with conventional cooking than that of new approach of cooking methods. The lower color score of conventional and commercial cooking method might be related with the pale color after grilling. The surface of the Chuncheon Dakgalbi was burned and caused pale-darker color due to the direct intact with the hot pan while it was grilled. The new approach of cooking method also increased the sensory evaluation scores of texture. Judge et al. (1989) reported that the moist heat provide relatively huge amount of water that is needed in hydrolysis collagen and other connective tissues, and the collagen hydrolysis is play role on the tenderization of muscles ( $\mathrm{Ma}$ and Ledward, 2004). The retort packaging that isolate the water contained in meat from the evaporation during cooking might enhance the tenderization of meat during cooking. Judge et al. (1989) noted that the tenderization of moist heat cookery can be enhanced by wrapping the cuts in moisture proof materials that will trap the moisture. The retort packaging also might trap the volatile compounds as the component of meat flavor and aroma, so that the panels scored higher smell/aroma of Chuncheon Dakgalbi cooked with new approach of cooking than that of conventional cooking method. Finally, the overall acceptability of Chuncheon Dakgalbi cooked with new approach of cooking methods was higher than that of commercial cooking method.

The results showed that the new approach of cooking (packed with retort and cooked at heat and pressure) might be useful for the packaging of Chuncheon Dakgalbi made from spent laying hen and old broiler. On future, further study on the application of new approach cooking method (high temperature and pressure) of Chuncheon Dakgalbi is needed to study the possibility of the industrialization of Chuncheon Dakgalbi by retort packaging.

\section{Acknowledgement}

This research was supported by The Research Center for Export for Poultry Products (Project number 90800105-1-SB350), Ministry for Food, Agriculture, Forestry and Fisheries, Republic of Korea.

\section{References}

1. Aberle, E., Forrest, J., Gerrard, D., Mills, E., Hedrick, H., and Judge, M. (2001) Principles of Meat Science. 4th ed, Kendall-Hunt Publishing Company, Dubuque, IA.

2. AOAC (2007) Official Methods of Analysis. 18th ed, Association of Official Analytical Chemists, Washington, DC.

3. Beilken, S. L., Macfarlane, J. J., and Jones, P. N. (1990) Effect of high pressure during heat treatment on the warner-bratzler shear force values of selected beef muscle. J. Food Sci. 55, 15-18.

4. Bouton, P. E., Ford, A. E., Harris, P. V., Macfarlane, J. J., and O'shea, J. M. (1977) Pressure-heat treatment of post-rigor muscle: Objective subjective measurements. J. Food Sci. 42, 857-859.

5. Castellini, C., Mugnai, C., and Dal Bosco, A. (2002) Effect of organic production system on broiler carcass and meat quality. Meat Sci. 60, 219-225. 
6. Chen, G. H., Cheng, J. H., Shuiep, E. S., Bao, W. B., and Musa, H. H. (2006) Breed and sex effect on meat quality of chicken. Inter. J. Poultry Sci. 5, 566-568.

7. Collins, N. E., and Moran, E. T. (1999) Influence of supplemental manganese and zinc on live performance and carcass quality of diverse broiler strains. J. Appl. Poultry Res. 8, 228235.

8. Cornforth, D. P., and Jayasingh, P. (2004) Colour and pigment. In: Encyclopedia of meat sciences. Jensen, W. K., Devine, C., and Dikeman, M., (ed) Elsevier Ltd., Oxford, pp. 249-256.

9. Ding, H., Xu,R. J., and Chan, D. K. O. (1999) Identification of broiler chicken meat using a visible/near-infrared spectroscopic technique. J. Sci. Food Agric. 79, 1382-1388.

10. Fletcher, D. L. (2002) Poultry meat quality. World's Poultry Sci. J. 58, 131-145.

11. Franco, D., Rois,D., Vazquez, J. A., and Lorenzo, J. M. (2012) Comparison of growth performance, carcass components, and meat quality between Mos rooster (Galician indigenous breed) and Sasso T-44 line slaughtered at 10 months. Poultry Sci. 91, 1227-1239.

12. Gekko, K., and Koga, S. (1983) Increased thermal stability of collagen in the presence of sugars and polyols. J. Biochem. 94, 199-205.

13. Gerrard, D. E. and Grant, A. L. (2006) Principles of animal growth and development. $1^{\text {st }}$ ed, Kendall/Hunt Publishing Co., Dubuque, IA.

14. Grau, R. and Hamm, R. A. (1953) A simple method for the determination of water binding in muscles. Naturwissenschaften 40, 29-30.

15. Hammes, W. P. (2012) Metabolism of nitrate in fermented meats: The characteristics feature of a specific group of fermented foods. Food Microbiol. 29, 151-156.

16. Jaturasitha, S., Srikanchai, T.,Kreuzer, M., and Wicke, M. (2008) Differences in carcass and meat characteristics between chicken indigenous to Northern Thailand (Black-Boned and Thai native)and imported extensive breeds (Bresse and Rhode Island Red). Poultry Sci. 87, 160-169.

17. Jay, J. M. and Shelef, L. A. (1978) Microbial modification in raw and processed meats and poultry at low temperature. Food Technol.32, 186-187.

18. Jin, S. K., Kim, I. S., Jung, H. J., Kim, D. H., Choi, Y. J., and Hur, S. J. (2007) The development of sausage including meat from spent laying hen surimi. Poultry Sci. 86, 2676-2684.

19. Judge, M. D., Aberle, E. D., Forrest, J. C., Hedrick, H. B., and Merkel, R. A. (1989) Principles of meat science. $2^{\text {nd }}$ ed,
Kendall/Hunt Publishing Company, Dubuque, IA, pp. 271287.

20. Kohsaka, K. (1975) Freshness preservation of food and measurement. Food Industry 18, 105-111.

21. Lee, S. K., Kim, H. J., Kang, S. M., Choi, W. H., Muhlisin, Ahn, B. K., Kim, C. J., and Kang, C. W. (2011) Quality comparison of Chuncheon Dakgalbi made with Ross broilers, Hy-line brown chicks and White mini broilers meat. Korean J. Poultry Sci. 38, 113-119.

22. Ma, H. J. and Ledward, D. A. (2004) High pressure/thermal treatment effects on the texture of beef muscle. Meat Sci.68, 347-355.

23. Miguel, J. A., Asenjo,B., Ciria, J., and Clavo, J. L. (2008) Effect of caponisation on growth and on carcass meat characteristics in CastellanaNegra native Spanish chicken. Animal 2, 305-311.

24. Nychas, G. J. E., Drosinos, E. H., and Board, R. G. (1998) Chemical changes in stored meat. In: The Microbiology of Meat and Poultry. Blackie Academic and Professional, London, pp. 288-326.

25. Shahidi, F. (1998) Flavor of meat, meat products and sea foods. $2^{\text {nd }} \mathrm{ed}$, Blackie academic and professional, London, UK.

26. Sindelar, J. J. and Milkowski, A. L. (2011) Sodium nitrite in processed meat and poultry meats: a review of curing and examining the risk/benefit of its use. AMSA white paper series 3, 1-14.

27. Sinnhuber, R. O. and Yu, T. C. (1977) The 2-thiobarbituric acid reaction, an objective measure of the oxidative deterioration occurring in fats and oils. J. Jpn. Soc. Fish Sci. 26, 259-267.

28. Smith, D. P., Northcutt, J. K., and Steinberg, E. L. (2012) Meat quality and sensory attributes of a conventional and a label rouge-type broiler strain obtained at retail. Poultry Sci. 91, 1489-1495.

29. Wang, K. H., Shi, S. R., Dou, T. C., and Sun H. J. (2009) Effect of a free-range raising system on growth performance, carcass yield, and meat quality of slow-growing chicken. Poultry Sci. 88, 2219-2223.

30. Wattanachant, S., Benjakul, S., and Ledward, D. A. (2004) Composition, color, and texture of Thai endigenous and broiler chicken muscles. Poultry Sci. 83, 123-128.

(Received 2012.7.9/Revised 2012.10.25/Accepted 2012.11.6) 